\title{
To Assess Effectiveness of Planned Teaching Program on Knowledge Regarding Eye Donation among Students in Selected Junior College of Navi Mumbai
}

\author{
Sudershna P. Lal* \\ Department of Community Health Nursing, Bharati Vidyapeeth (Deemed to be University), Navi Mumbai, Maharashtra, India
}

\section{Abstract}

Background: Eyes are one of the most important sensory organs in the human body, which renders vision and power to see. The act of donating one's eye after his/her death is eye donation. Eye donation is act of charity, purely for the benefit of the society, and it's totally voluntary.

\begin{abstract}
Aims and Objectives: The aim of the study was to assess the effectiveness of planned teaching program on knowledge regarding eye donation among students in selected junior college of Navi Mumbai, to assess the knowledge regarding eye donation among the junior college students before planned teaching program, to assess the effectiveness after planned teaching program on knowledge regarding eye donation among the junior college students by comparing pre-test and post-test knowledge scores, and to determine the association between pretest knowledge score in relation to selected demographic variable.
\end{abstract}

Materials and Methods: The research approach is quantitative and the research design is quasi-experimental design and non-probability convenient sampling technique is used. The sample of the study was 50 from Bharati Vidyapeeth Junior College, Belapur. Structured questionnaire is the tool used for data collection. Demographic and knowledge on eye donation were analyzed using descriptive statistics.

Results: The 50 samples from Bharati Vidyapeeth Junior College, Belapur, were taken for data collection. The pre-test knowledge score is that samples with poor knowledge were $1.60 \%$ while average knowledge score were $60 \%$, good knowledge were $38.33 \%$, and excellent knowledge were 0 . In post-test, the sample with poor knowledge score was 0 while average knowledge were $6.66 \%$, good knowledge were $65 \%$, and excellent were $28.33 \%$. By $t$-test, the two-tailed $P<0.0001$ was obtained, and by conventional criteria, the difference is considered to be extremely significant.

Conclusion: As per findings and interpretation of the data analysis, the result shows that planned teaching program is useful for the junior college students to update their knowledge regarding eye donation.

Keywords: Eye donation, knowledge, planned teaching program, students

\section{INTRODUCTION}

Eyes are one of the most important sensory organs in human body as they render vision and the power to see. The people with visual impairedness feel that their life is incomplete as they can just feel, touch, and smell but cannot see. ${ }^{[1]}$

\section{Access this article online}

Website: http://innovationalpublishers.com/Journal/ijnmi

ISSN No: $2656-4656$

DOI: $10.31690 /$ ijnmi.2020.v05i02.003
The act of donating one's eye after his/her death is eye donation. When the eye is affected only by corneal diseases, replacing this part will restore the vision in such people. Corneal diseases are the significant causes of visual impairment and blindness in the world. Corneal blindness is due to scarring or clouding of the normally transparent cornea. The cornea is clear tissue covering the front of the eye. It is a focusing element of the eye. ${ }^{[2]}$ The major causes of corneal blindness include trachoma, corneal ulceration following xerophthalmia due to Vitamin A deficiency, ophthalmia neonatorum, and leprosy. Age or systemic illness such as diabetes or hypertension, heart disease, and kidney disease is not barriers for eye donation.

Address for Correspondence:

Sudershna P. Lal, Department of Community Health Nursing, Bharati Vidyapeeth (Deemed to be University), Navi Mumbai, Maharashtra, India.

E-mail: sudershna2402@gmail.com

This is an open-access journal, and articles are distributed under the terms of the Creative Commons Attribution Noncommercial Share Alike 4.0 License, which allows others to remix, tweak, and build upon the work non-commercially, as long as appropriate credit is given and the new creations are licensed under the identical terms 
The cornea of a person is unaffected even if they undergone any eye surgery in the past and hence will be useful and can be transplanted in others. Only corneal blinds can be benefitted through the process and not the other blinds. ${ }^{[3]}$

As worldwide, there is severe shortage of corneal donor available worldwide, the need of patients of corneal transplant is greatly exceeding than the number of corneal tissue available. In this review, there are about 38,851 respondents across all included studies, $52 \%$ endorsed a willingness to donate their eyes after death, while only $5 \%$ reported being a pledged donor. The most common cited reason for not being registered for eye donation was lack of awareness about eye donation. So for increasing the awareness regarding eye donation could be addressed through educational media campaigns. Collaboration with medical personnel, use of social media and educational session with medical students and staff. ${ }^{[4]}$

There are widespread social awareness programs and activities conducted across the country to impart the significance of eye donation and its usefulness to the visually impaired people. The programs which are established mainly for the blindness are like "Vision 2020." It is the global initiative "The Right to Sight" was launched in 1999 with the twins aim of eliminating avoidable blindness by the year " 2020 " and preventing the projected doubling of avoidable visual impairment between 1990 and 2020. Till the date, medical researchers and scientists are working on developing artificial cornea, but till that time, donating the eyes would be the best gift ever for a blind person suffering from corneal blindness. ${ }^{[5]}$

Eye donation is the act of charity, purely for the benefit of the society and it's totally voluntary. To enable, another person obtain vision is one of the best forms of the charity. Even after the death, the donor lives in the eyes of recipient. Eyes from a dead person can enable two-blind people to acquire vision. ${ }^{[6]}$

About 285 million people are visually impaired worldwide: 39 million are blind and 246 million have low vision (sever or moderate visual impairment). About $90 \%$ of the world's visually impaired people live in developing countries. About $65 \%$ of visually impaired and $82 \%$ of blind people are over 50 years of age, although this age group comprises only $20 \%$ of world population. The top cases of visual impairment: Refractive errors, cataract, and glaucoma top cases of blindness cataract glaucoma and age-related macular degeneration. ${ }^{[7]}$

The country with 156 eye banks (39 in Maharashtra) manage to collect maximum of just 25,000 of eyes and $30 \%$ of which cannot be used due to some degeneration or diseases.

As per the reports furnished by states/union territories, less than $50 \%$ donated eyes collected under the National Programme for Control of Blindness of the Ministry of Health and Family Welfare are utilized for corneal transplantation. It is mainly because all the donated eyes are not found suitable for corneal transplantation due to various medical reasons like poor quality of collected corneas due to reasons such as pre-existing degeneration/diseases. ${ }^{[8]}$
However, corneas not suitable or fit for optical keratoplasty are utilized either for therapeutic keratoplasty or for training and research purposes. No report about intentional non-use/ wastage of donated eyes in government eye banks/hospital across the country has been received. Information, education, and communication is ongoing activity under. The National Programme for Control of Blindness to create awareness about eye health including promotion of eye donation to restore vision of corneal blind in the country. Educating people about early donation so that eye tissues can be harvested within 4-6 $\mathrm{h}$ of death of donor. Promotion of eye donation through print and electronic media and a weekly radio program - "Ankehn Hain Anmol" aired on FM Gold. ${ }^{[9]}$

Nationally in the financial year 2017-18, a total of 57,138 corneas were collected and 26,143 transplant surgeries were carried out, according to the Eye Bank Association of India. Besides about this, 20,000-30,000 new cases get added every year where it's huge need for the availability for transplant donor worldwide to reduce the burden of blindness. ${ }^{[10]}$

The objective of the study was to assess the knowledge regarding eye donation among the junior college students before planned teaching program, to assess the effectiveness after planned teaching program on knowledge regarding eye donation among the junior college students by comparing pre-test and post-test knowledge scores, and to determine the association between pretest knowledge score in relation to selected demographic variable.

\section{Methodology}

Research methodology or design refers to the researcher overall plan for addressing a research a research question, including specification for enhancing the integrity of the study. Research methodology is a way to solve problem systematical provides a systematic course of action for the researcher to progress toward the end of study.

The current study deals with the methodology used by the researchers to study the effectiveness of plan teaching program on awareness of eye donation among the junior college students.

\section{Research approach}

Research approach indicates the basic procedure for conducting research. Choice of the appropriate approaches depends on the purpose of the study. (DENISE F POLIOT, nursing research, seventh edition). A quasi-experimental approach was used for the study of the effectiveness of plan teaching program on awareness of eye donation among the junior college student.

\section{Research design}

It is an overall plan for how to obtain answer to question, being studied how to handle some of the difficulties encountered clearly is research process. Quasi-experimental one-group pretest-posttest design is used for the study, as shown in Figure 1. 


\begin{tabular}{llll}
\hline Pretest $\rightarrow$ & $\begin{array}{l}\text { Treatment } \\
\text { or } \\
\text { intervention } \\
\bigcirc_{1}\end{array}$ & $\rightarrow$ & Posttest \\
$\bigcirc_{1}$ & $\bigcirc_{2}$ \\
\hline
\end{tabular}

Figure 1: Pretest-posttest design

\section{Variables}

Dependent variables: The dependent variable of this study is knowledge of junior college students regarding eye donation.

Independent variables: The independent variable is the planned teaching programmed on eye donation.

Demographic variable: Characteristics of students such as age and sex.

\section{Setting of the study}

The study is conducted in Bharati Vidyapeeth Junior College, Belapur.

\section{Population}

A population is a complete set of person or objects that possess some common characteristics that are of interest to the researcher. In the present study, the assessment was performed on the student of Bharati Vidyapeeth Junior College, Belapur.

\section{Sample}

A sample is used in research when it is not feasible to study the whole population from which it is drawn. "A sample is a small portion of the population selected to participate in the research study" (Polit and Hungler, 1991).

\section{Sample selection criteria}

The following criteria were set to select samples:

\section{Inclusion criteria}

The following criteria were included in the study:

1. Pupil who are willing.

2. Pupil of the $1^{\text {st }}$ year junior college only.

3. Pupil age between 15 and 17 years of age.

\section{Exclusion criteria}

The following criteria were excluded from the study:

1. Pupil with psychological disorder.

2. Pupil who were available at the time of data collection.

\section{Sample size}

Total sample size for this study is 60 students from Bharati Vidyapeeth Junior College, Belapur, Navi Mumbai.

\section{Sample technique}

In the current study, non-probability convenient sampling technique is used by the investigator for the selection of sample. It was suitable keeping in view the time provided for data collection, permission, granted by concern authorities of the junior college.

\section{Data collection tool}

The most important and crucial aspects of any research are data collection, which give answer to the question of the study.

The current study aims at assessing the effectiveness of plan teaching program on awareness of eye donation among the junior college students. A structured questionnaire is used as tool for data collection.

\section{Development of tool}

The current study aimed at assessing the effectiveness of planned teaching program on knowledge regarding eye donation among selected junior college students of Navi Mumbai.

In the study, the investigator used structured questionnaire tool, in printed structured questionnaire tool considering multiple-choice questions to evoke knowledge of eye donation.

The tool was developed to achieve the objectives of the study. The researchers adopted the following steps in the development of the tools.

1. Review of literature provided adequate content for the tool preparation on awareness of eye donation.

2. Personal opinion, suggestions, and discussion with the experts.

3. Construction of demographic data tool and structured knowledge questionnaire on awareness of eye donation.

4. Content validity.

\section{Description of tool}

The researcher prepared a tool for the study. The structured questionnaire tools consist of two sections:

\section{Section 1: Demographic tool}

It consists of 8 items to assess their demographic data, namely, age, gender, family, religion, residence, number of family member, monthly income, and highest degree of level of education completed in family.

\section{Section 2: Structured knowledge questionnaire}

It consists of a 20 items to assess the knowledge of eye donation among the junior college students.

\section{Structured questionnaire}

All 20 questions are multiple-choice questions with four options as answer. One mark (+1) will be allotted for each right answer and 0 marks given for each incorrect answer. The range of possible score varies for minimum 0 to maximum 20 marks, as shown in Table 1. 


\section{Validity}

"Validity means to what extended measure and what it claims to measure. Validity is the degree of precision with which the test employed really measures, what is intended to measure." by Gilbert.

The structured interview tools and planned teaching program were given to five experts along with the blue print and objectives of the study to establish the content validity of the tool and plan teaching program regarding knowledge on eye donation. The experts were from the field of nursing and medical research department. They were requested to give their viewpoint and recommendation regarding the appropriateness of the item in the tool.

By the experts, suggestion on modification in question related to demographic data and addition of more in-depth question related to eye donation was correctively followed.

All the experts gave the opinion to make the planned teaching program in brief and in language which was easily understandable. Both the structured questionnaire tool and PowerPoint presentation were prepared in English language. Expert established the validity of the tool, Table 2.

\section{Procedure of data collection}

Prior final study, a formal permission is obtained January 9, 2019, from the principal of Bharati Vidyapeeth Junior College of Belapur, Navi Mumbai. Data were collected on January 18, 2019. After identifying the samples, objectives of the study were discussed and consent for the participation in the study was taken from the selected group. The investigator assured the subject about the confidentiality of the data. The investigator herself administered the questionnaire for the pre-test. During the pre-test, participants were seated away from each other and discussion was not allowed among the students to avoid bias. The planned teaching program on eye donation was disseminated to the experimental group after the pre-test and a brief introduction.

A total of 60 samples selected for the main study. Planned teaching program followed by pre-test in a single session and

Table 1: Scoring system of the tool

\begin{tabular}{lc}
\hline Interpretation & Scoring \\
\hline Poor & $0-5$ \\
Average & $6-10$ \\
Good & $11-15$ \\
Excellent & $16-20$ \\
\hline
\end{tabular}

Table 2: Representation of data collection

\begin{tabular}{|c|c|c|c|c|c|}
\hline \multirow{2}{*}{$\begin{array}{l}\text { Name of } \\
\text { college }\end{array}$} & \multirow{2}{*}{$\begin{array}{l}\text { Sample } \\
\text { size }\end{array}$} & \multirow{2}{*}{$\begin{array}{c}\text { Time } \\
\text { allotted }\end{array}$} & \multicolumn{3}{|c|}{ Date and duration } \\
\hline & & & Pre-test & $\begin{array}{c}\text { Plan } \\
\text { teaching } \\
\text { program }\end{array}$ & Post-test \\
\hline $\begin{array}{l}\text { Bharati } \\
\text { Vidyapeeth }\end{array}$ & 60 & $\begin{array}{c}10 \text { am-12 } \\
\text { am (2h) }\end{array}$ & $\begin{array}{c}\text { January } \\
18,2019\end{array}$ & $\begin{array}{c}\text { January } 18, \\
2019\end{array}$ & $\begin{array}{c}\text { January } \\
30,2019\end{array}$ \\
\hline $\begin{array}{l}\text { Junior } \\
\text { College, } \\
\text { Belapur }\end{array}$ & & & $30 \mathrm{~min}$ & $1 \mathrm{~h}$ & $30 \mathrm{~min}$ \\
\hline
\end{tabular}

duration of teaching was $1 \mathrm{~h}$. Post-test was conducted on the $12^{\text {th }}$ day. The instruction about post-test was given to the respective participants of the group. Time taken for post-test by each sample was approximately $30 \mathrm{~min}$. After the data collection was over, all the participants were thanked for their participation and cooperation in the study. The analysis is made on the basis of objective and hypothesis. The data analysis is plan's to include descriptive statistics. Data analysis is in the following parts:

Part 1: Analysis of demographic data of sample using descriptive statistics.

Part 2: Analysis of knowledge before plan teaching program is done by inferential statistics.

Part 3: Analysis regarding effectiveness of plan teaching program by inferential statistics paired $t$-test.

Part 4: Analysis regarding association between pre-test knowledge score and demographic variable by Chi-square test.

\section{REsULTS}

\section{Section I: Analysis of the demographic data of the samples}

In this section, demographic data of the sample have been display to show the frequency distribution of the various attributes of demographic variables. With the help of various graphs, outcome of demographic data is as follows:

Table 3 data state that $8.3 \%$ of students are belonging to age group of $17-18$ years, whereas $76.6 \%$ of students are belonging to the age group of 16-17 years.

Table 4 states that $68.4 \%$ of students are male and $31.6 \%$ of students are female.

Table 5 indicates that $61 \%$ of samples are belonged to nuclear family, whereas $27 \%$ of students are belonged to joint family.

Table 6 indicates that $85 \%$ of students are Hindu, $6 \%$ of students are Christian, and Muslim students are $8.3 \%$.

Table 3: Age demographic data of sample

\begin{tabular}{lcc}
\hline Age in years & Frequency & Percentage \\
\hline $15-16$ & 9 & 15 \\
$16-17$ & 46 & 76.6 \\
$17-18$ & 5 & 8.3 \\
\hline
\end{tabular}

Table 4: Gender demographic data of the sample

\begin{tabular}{lcc}
\hline Gender & Frequency & Percentage \\
\hline Male & 41 & 68.4 \\
Female & 19 & 31.6 \\
\hline
\end{tabular}

Table 5: Type of family demographic data of the sample

\begin{tabular}{lcc}
\hline Family & Frequency & Percentage \\
\hline Joint & 16 & 26.6 \\
Nuclear & 37 & 61.6 \\
Single & 6 & 10 \\
Extended & 1 & 1.6 \\
\hline
\end{tabular}


Table 7 states that $87 \%$ of students are staying in building, $5 \%$ of students are staying in chawl, and other 85 students have bungalow.

Table 8 states that $81.6 \%$ of students are staying with $3-5$ members of family, $11.6 \%$ of students are in family with $6-10$ members, and only $1.6 \%$ of students are having $1-2$ members in family.

Table 9 states that majority (43.3\%) of students family monthly income is more than 30,000 Rs., $28.3 \%$ family is earning $10,000-20,000$ Rs. in a month, and only $15 \%$ of students family's monthly income is $<10.000$ Rs.

Table 10 states that majority of family members $(40 \%)$ are educated with bachelor degree, $36.6 \%$ of students family members are educated with high school certificate and only $6.6 \%$ of students family is honored with doctorate degree.

Table 11 indicates that $86.6 \%$ of student's family members have no profession in Medicity, 3.3\% of nurses are noticed in students family, and $5 \%$ of students have doctor in their family.

Table 12 states that majority of students (45\%) have known about eye donation through social media, $43 \%$ of students have known through TV/news/books, and only $2 \%$ of students have never heard about eye donation as they have never heard about it.

Table 6: Religion demographic data of samples

\begin{tabular}{lcc}
\hline Religion & Frequency & Percentage \\
\hline Hindu & 51 & 85 \\
Muslim & 5 & 8.3 \\
Christian & 1 & 1.6 \\
Other & 3 & 5 \\
\hline
\end{tabular}

Table 7: Residence demographic data of samples

\begin{tabular}{lcc}
\hline Residence & Frequency & Percentage \\
\hline Bungalow & 3 & 5 \\
Building & 52 & 86.6 \\
Chawl & 5 & 8.3 \\
\hline
\end{tabular}

Table 8: Total members in family demographic data of samples

\begin{tabular}{lcc}
\hline Total members & Frequency & Percentage \\
\hline $1-2$ & 1 & 1.6 \\
$3-5$ & 49 & 81.6 \\
$6-10$ & 7 & 11.6 \\
Above 10 & 3 & 5 \\
\hline
\end{tabular}

Table 9: Total family income demographic data of samples

\begin{tabular}{lcc}
\hline Income in Rs. & Frequency & Percentage \\
\hline Below 10,000 & 9 & 15 \\
10,000-20,000 & 17 & 28.3 \\
20,000-30,000 & 8 & 13.3 \\
Above 30,000 & 26 & 43.3 \\
\hline
\end{tabular}

Table 13 indicates that $76.6 \%$ of students surrounding have never done eye donation.

\section{Section II: Analysis of Data Related to Effectiveness of Planned Teaching Program on Knowledge Regarding Eye Donation}

In this section, as per the score, interpretation frequency and percentage of pre-test and post-test have been calculated to compare the knowledge level of samples regarding eye donation. While in the second table, description of significant difference between pre-test and post-test by paired sample test is shown.

Table 14 indicates that pre-test score of poor knowledge was $1.6 \%$, while in post-test score, the poor knowledge is $0 \%$. The pre-test of excellent knowledge is $0 \%$ while post-test score of excellent knowledge is $28.33 \%$

To find out significant difference between mean pre-test and post-test score, paired " $t$ " test was computed and data are presented in Table 15 to test the statistical difference following null hypothesis stated. The mean difference of pre-test and post-test value is 4.33 while that " $t$ " value is 11.6079 . To find

Table 10: Highest degree or level of education demographic data of samples

\begin{tabular}{lcc}
\hline $\begin{array}{l}\text { Highest degree or level of education in } \\
\text { family }\end{array}$ & Frequency & Percentage \\
\hline High school & 22 & 36.6 \\
Bachelor & 24 & 40 \\
Master & 10 & 16.6 \\
Doctorate & 4 & 6.6 \\
\hline
\end{tabular}

Table 11: Medical professional in family demographic data of samples

\begin{tabular}{lcc}
\hline Medical professional in family & Frequency & Percentage \\
\hline Doctor & 3 & 5 \\
Nurse & 2 & 3.3 \\
Any other & 3 & 5 \\
No & 52 & 86.6 \\
\hline
\end{tabular}

Table 12: Eye donation known through demographic data of samples

\begin{tabular}{lcc}
\hline $\begin{array}{l}\text { Have you heard about eye donation } \\
\text { through }\end{array}$ & Frequency & Percentage \\
\hline Conference/lecture & 6 & 10 \\
TV/news/books & 26 & 43.3 \\
Social media & 27 & 45 \\
Never heard & 1 & 1.6 \\
\hline
\end{tabular}

Table 13: Eye donation done by demographic data of samples

\begin{tabular}{lcc}
\hline $\begin{array}{l}\text { Have anyone in your family done eye } \\
\text { donation by }\end{array}$ & Frequency & Percentage \\
\hline Family & 8 & 13.3 \\
Neighbor & 2 & 3.3 \\
Friend & 4 & 6.6 \\
None & 46 & 76.6 \\
\hline
\end{tabular}


Sudarshna

Table 14: Comparison between pre-test and post-test knowledge score

\begin{tabular}{llcccc}
\hline Range & Interpretation & \multicolumn{2}{c}{ Pre-test } & \multicolumn{2}{c}{ Post-test } \\
\cline { 3 - 5 } & & Frequency & Percentage & Frequency \\
\hline $0-5$ & Poor & 1 & 1.60 & 0 & Percentage \\
$6-10$ & Average & 36 & 60 & 4 & 0.66 \\
$11-15$ & Good & 23 & 38.33 & 39 & 65 \\
$16-20$ & Excellent & 0 & 0 & 17 & 28.33 \\
\hline
\end{tabular}

out the association between pre-test knowledge and selected demographic variables such as any medical professional in your family, have you heard about eye donation through and, in my knowledge, eye donation is done by.

In Table 16, the Chi-square is $11.747, P=0.227954$. The results are not significant at $P<0.05$.

In Table 17, the Chi-square statistic is $7.05, P=0.63191$. The result is not significant at $P<0.05$.

In Table 18, the Chi-square statistic is 11.2682, $P=0.257773$. The result is not significant at $P<0.05$.

\section{Discussion}

The findings of this study have been discussed with the reference to the objectives and hypothesis. The study findings of demographical variables state that the majority of the samples were in the age group of 16-17 years of age that is $76.6 \%$. The findings related to gender of the samples in that male were $68.4 \%$ and females were $31.6 \%$. The findings related to religion were that $85 \%$ of them were Hindu and the least was them which were Christian $1.6 \%$. The findings related to residence were in building $86.6 \%$ and least was in bungalow $5 \%$. The findings related to monthly income in rupees of the family were majority above 30,000 that is $43.3 \%$ and $13.3 \%$ were from 20,000 to 30,000 . The findings related to higher degree or level of education of the family members were majority from bachelor degree $40 \%$ and only $6.6 \%$ were from doctorate degree. The findings related to no one in medical professional in family were $86.6 \%$ and $3.3 \%$ were nurses. The findings related to heard of eye donation are majority from TV/ news/books $43 \%$ and $2 \%$ have no idea about eye donation. The findings related to eye donation done in their surrounding were no one have done is $76.6 \%$ and neighbor were $3.3 \%$.

The findings related to knowledge score in pre-test poor knowledge were $1.6 \%$, average knowledge level were $60 \%$, good knowledge level were $38.3 \%$, and excellent knowledge were 0 . In post-test findings, poor knowledge level was $0 \%$ and average knowledge score was $6.6 \%$, good knowledge score was $65 \%$, and excellent knowledge score was $28.33 \%$. By $t$-test, the two-tailed $P<0.0001$ was obtained. By conventional criteria, the difference is considered to be extremely significant. In this study, it is found that association between the knowledge score and selected demographic variables has no statistical significance as there is no significance found at $P<0.05$ by applying Chi-square test. A study was done to know the knowledge and attitude of college students toward eye donation. A cross-sectional study by
Table 15: Significant difference between the mean pretest and post-test knowledge score of subject on eye donation

\begin{tabular}{lcccc}
\hline Test & Mean & $\begin{array}{c}\text { Mean } \\
\text { difference }\end{array}$ & $\begin{array}{c}\text { Standard deviation } \\
\text { difference }\end{array}$ & " $\boldsymbol{t}$ " value \\
\hline Pre-test & 9.32 & 4.33 & 2.18 & 11.6079 \\
Post-test & 13.65 & & 2.75 & \\
\hline
\end{tabular}

pre-structured and pre-tested questionnaire was done, in which they have taken 403 students from eight different colleges, in which $96 \%$ of students were aware of eye donation and acknowledged that they can donate eyes after death. Majority $61 \%$ know that eye should be donated within $6 \mathrm{~h}$. About $69 \%$ believe that there is no age limit for eye donation. About $68 \%$ are of opinion that eye donation will not cause disfigurement of face among them females were more aware than males. About $33.4 \%$ know that only cornea is used in eye transplantation. About $78.1 \%$ are willing to donate eyes. The study concludes that youth and students are willing to donate their eyes after death, but there were many stigma and misbelieves were also noted among the students that weak eye sight, religious belief, and social stigma do not allow for eye donation. ${ }^{[1]}$

The total respondents were 947 in which 481 (50.79\%) were male and 466 (49.21\%) were female. The awareness of eye donation was present in $590(62.30 \%)$ while $357(37.70 \%)$ were not aware. They concluded that the awareness regarding eye donation should be increased so that the public's attitude would be more favorable to facilitate and increase in the number of corneas available for transportation. ${ }^{[12]}$

The majority of the participants $97.9 \%$ were aware of the existence of eye donation. Mass media $62.9 \%$ was the foremost source of information. However, only 145 participants were willing to donate their eyes. Only 60 participants were aware that the whole eye can be removed from the donor while 215 were wrongly aware that the cornea can be removed separately. Awareness about eye donation was not associated with willingness to donate eyes. The conclusion of the study was noted that awareness regarding eye donation was satisfactory, as there was lack of willingness to donate eyes. There is a need to bridge the gap between eye bank and donors. ${ }^{[13]}$

The knowledge regarding the number of hours within which eye should be removed for donation was good (67.4\%) in this study as compared to $38 \%$ among nursing students at Bengaluru and $39.7 \%$ in the study. Only $40 \%$ of the students knew that it takes $<1 \mathrm{~h}$ for removing eyes after death. ${ }^{[14]}$ 
Table 16: Any medical professional in family

\begin{tabular}{lcccrr}
\hline Any medical professional in family & Poor & Average & Good & Excellent & Row Total \\
\hline Doctor & $1(0.40)[0.90]$ & $3(2.80)[0.01]$ & $1(2.40)[0.82]$ & $1(0.40)[0.90]$ & 6 \\
Nurse & $1(0.33)[1.33]$ & $2(2.33)[0.05]$ & $1(2.00)[0.50]$ & $1(0.33)[1.33]$ & 5 \\
Any other & $1(0.40)[0.90]$ & $3(2.80)[0.01]$ & $1(2.40)[0.82]$ & $1(0.40)[0.90]$ & 6 \\
No & $1(2.87)[1.22]$ & $20(20.07)[0.00]$ & $21(17.20)[0.84]$ & $1(2.87)[1.22]$ & 43 \\
Column totals & 4 & 28 & 24 & 4 & $60(\mathrm{Grand} \mathrm{Total)}$ \\
\hline
\end{tabular}

Table 17: Have you heard about eye donation through

\begin{tabular}{lccccc}
\hline Have you heard about eye donation through & Poor & Average & Good & Excellent & Row totals \\
\hline Conference & $1(0.53)[0.41]$ & $4(3.87)[0.00]$ & $2(3.07)[0.37]$ & $1(0.53)[0.41]$ & 8 \\
Television & $1(1.67)[0.27]$ & $12(12.08)[0.00]$ & $11(9.58)[0.21]$ & $1(1.67)[0.27]$ & 25 \\
Social media & $1(1.53)[0.19]$ & $12(11.12)[0.07]$ & $9(8.82)[0.00]$ & $1(1.53)[0.19]$ & 23 \\
Never heard & $1(0.27)[2.02]$ & $1(1.93)[0.45]$ & $1(1.53)[0.19]$ & $1(0.27)[2.02]$ & 4 \\
Column totals & 4 & 29 & 23 & 4 & $60(\mathrm{Grand} \mathrm{Total)}$ \\
\hline
\end{tabular}

Table 18: Knowledge eye donation

\begin{tabular}{lccccc}
\hline In my knowledge, eye donation is done by & Poor & Average & Good & Excellent & Row totals \\
\hline Family members & $1(0.67)[0.17]$ & $6(5.00)[0.20]$ & $2(3.67)[0.76]$ & $1(0.67)[0.17]$ & 10 \\
Neighbors & $1(0.27)[2.02]$ & $1(2.00)[0.50]$ & $1(1.47)[0.15]$ & $1(0.27)[2.02]$ \\
Friend & $1(0.40)[0.90]$ & $3(3.00)[0.00]$ & $1(2.20)[0.65]$ & $1(0.40)[0.90]$ & 4 \\
No one & $1(2.67)[1.04]$ & $20(20.00)[0.00]$ & $18(14.67)[0.76]$ & $1(2.67)[1.04]$ & 6 \\
Column totals & 4 & 30 & 22 & 40 & $60($ Grand Total) \\
\hline
\end{tabular}

These data also showed that participants had a positive attitude toward organ donation (44.9; range 14-56), with approximately $72 \%$ having a favorable view. However, while $40 \%$ of the participating students stated their intentions to donate their organs, only $23 \%$ of them had donor cards. The conclusion was that medical students have a positive attitude toward organ donation. However, a substantial lack of knowledge of organ donation among our subjects is a barrier to their taking the necessary measures to become active donors. ${ }^{[15]}$

Out of the 395 participants, 317 (80.5\%) were aware of eye donation, $312(80 \%)$ knew that the cornea is used for eye donation, and 294 (76\%) knew that the ideal time for eye donation is within $6 \mathrm{~h}$ of death. Only $286(72.4 \%)$ knew about pledging for eye donation and only 251 (65.4\%) consented for pledge of their eyes. Of those who did not want to pledge, 12 $(14.8 \%)$ had religious reasons, $9(11.1 \%)$ feared disfigurement, $9(11.1 \%)$ thought that they might be born blind in their next birth, and $51(63 \%)$ had some other reasons. This will ultimately enhance the eye donation program in the country to help cope with the backlog in the long term. ${ }^{[16]}$

\section{ConcLusion}

The present study is conducted to assess the effect of planned teaching program regarding eye donation among the selected junior college students. The purpose of the study was to assess the knowledge of the students regarding eye donation.

\section{RefEREnCES}

1. Jay M. Downcast Eyes: The Denigration of Vision in Twentieth-century French thought. Berkeley, California: University of California Press; 1993.

2. Seiler MJ, Aramant RB. Cell replacement and visual restoration by retinal sheet transplants. Prog Retin Eye Res 2012;31:661-87.
3. Purnell TS, Hall YN, Boulware LE. Understanding and overcoming barriers to living kidney donation among racial and ethnic minorities in the United States. Adv Chronic Kidney Dis 2012;19:244-51.

4. Williams AM, Muir KW. Awareness and attitudes toward corneal donation: Challenges and opportunities. Clin Ophthalmol 2018;12:1049.

5. World Health Organization. Global Initiative for the Elimination of Avoidable Blindness: Action Plan 2006-2011.

6. Simpson B. Impossible gifts: Bodies, Buddhism and bioethics in contemporary Sri Lanka. J R Anthropol Institute 2004;10:839-59.

7. Gundewar PP, Abhyankar HK. A review on an obstacle detection in navigation of visually impaired. Int Org Sci Res J Eng 2013;3:1-6.

8. SinghAK. The Potential of Human Adipose Tissue Derived Mesenchymal Stem Cells in Cell Therapy for Retinal Degenerative Diseases; 2013. Available from: https://www.uvadoc.uva.es/handle/10324/4380. [Last accesseed on 2020 Jun 18].

9. Verma R, Khanna P, Prinja S, Rajput M, Arora V. The national programme for control of blindness in India. Aust Med J 2011;4:1.

10. Gupta N, Tandon R, Gupta SK, Sreenivas V, Vashist P. Burden of corneal blindness in India. Indian J Community Med 2013;38:198.

11. Nekar MS, Lokare L, Gokhale SA, Godbole M, Mulkipatil SY, Mahesh V. Awareness of eye donation among college students of Hubli city, Karnataka. Int J Biomed Res 2012;3:201-4.

12. Tiwari R, Diwakar A, Marskole P, Bhargo L, Anwar D. A study to assess awareness on eye donation and willingness to pledge eyes for donation in adult population in Gwalior district (MP), India. Int J Res Med Sci 2014;2:662-.

13. Lal B, Usgaonkar U, Narvekar H, Venugopal D. Awareness and knowledge on eye donation among Allied Health Sciences, medical, and nursing students in Goa. J Curr Ophthalmol 2018;30:255-62.

14. Kumar MP, Naik BS. To assess the knowledge of the undergraduate medical students regarding eye donation. Cornea 2013;135:67-4.

15. Marqués-Lespier JM, Ortiz-Vega NM, Sánchez MC, Soto-Avilés OE, Torres EA. Knowledge of and attitudes toward organ donation: A survey of medical students in Puerto Rico. Puerto Rico Health Sci J 2013;32:187-93.

16. Arya SK, Gupta N, Malik A. Eye donation awareness among medical and paramedical staff in a medical institute. Nepalese J Ophthalmol 2014;6:177-84.

How to cite this article: Sudarshna. To Assess Effectiveness of Planned Teaching Program on Knowledge Regarding Eye Donation among Students in Selected Junior College of Navi Mumbai. Int J Nurs Med Invest. 2020;5(2):20-26 